This is the accepted manuscript of the following article:

Yan, Y., Remhof, A., Rentsch, D., Züttel, A., Giri, S., \& Jena, P. (2015). A novel strategy for

reversible hydrogen storage in $\mathrm{Ca}(\mathrm{BH} 4) 2$. Chemical Communications, 51(55), 11008-11011.

http://doi.org/10.1039/C5CC03605D

\title{
A Novel Strategy for Reversible Hydrogen Storage in $\mathrm{Ca}\left(\mathrm{BH}_{4}\right)_{2}$
}

\author{
Yigang Yan, ${ }^{\text {ab }}$ Arndt Remhof, ${ }^{\text {ab }}$ Daniel Rentsch, ${ }^{c}$ Andreas Züttel, ${ }^{\text {bd }}$ Santanab Giri ${ }^{\mathrm{e}}$ and Puru Jena ${ }^{\mathrm{e}}$ \\ Received (in $X X X, X X X)$ Xth $X X X X X X X X X 20 X X$, Accepted Xth $X X X X X X X X X 20 X X$ \\ DOI: $10.1039 / b 000000 x$
}

\begin{abstract}
${ }_{5}$ We found that decomposition pathway of $\mathrm{Ca}\left(\mathrm{BH}_{4}\right)_{2}$ can be controlled by reaction temperature. That is, it decomposes into $\mathrm{CaB}_{6}$ at a lower temperature range of 320 to $350^{\circ} \mathrm{C}$, but into amorphous boron at 400 to $450^{\circ} \mathrm{C}$. We identified the formation of $\mathrm{CaB}_{2} \mathrm{H}_{6}$ as the crucial intermediate step on the 10 way to $\mathrm{CaB}_{6}$ that only forms at 320 to $350^{\circ} \mathrm{C}$.
\end{abstract}

Hydrogen is considered an ideal synthetic energy carrier to replace the limited fossil fuels. Wide utilization of hydrogen as a fuel strongly relies on its safe and efficient storage and transport, particularly for mobile applications. ${ }^{1,2}$ Light-weight metal 15 borohydrides display high hydrogen densities and thereby offer hope to overcome the challenges associated with solid hydrogen storage. ${ }^{3}$ In particular, some borohydrides display an enthalpy change in the decomposition reaction within the targeted window of $20-45 \mathrm{~kJ} / \mathrm{mol} \mathrm{H}_{2}$ for reversible on-board storage. For instance, ${ }_{20} \mathrm{Ca}\left(\mathrm{BH}_{4}\right)_{2}$ shows an enthalpy change of $36 \pm 4 \mathrm{~kJ} / \mathrm{mol} \mathrm{H}_{2}$ in the decomposition reaction into $\mathrm{CaB}_{6}$ according to Eq. 1.-6

$$
\mathrm{Ca}\left(\mathrm{BH}_{4}\right)_{2} \rightarrow 1 / 3 \mathrm{CaB}_{6}+2 / 3 \mathrm{CaH}_{2}+10 / 3 \mathrm{H}_{2}
$$

25 One of the main obstacles for metal borohydrides to be utilized as hydrogen storage materials is their poor reversibility. It is generally believed that boron sinks (i.e., amorphous $\mathrm{B}$ and/or $\left[\mathrm{B}_{12} \mathrm{H}_{12}\right]^{2-}$ phases) form during the decomposition and hinder rehydrogenation. One strategy to avoid the formation of boron 30 sinks is the addition of additives such as metals or metal hydrides to bind the boron in the form of a metal boride (e.g., $\mathrm{AlB}_{2}$ and $\mathrm{MgB}_{2}$ ) as the final product. For example, using $\mathrm{Al}$ or $\mathrm{MgH}_{2}$ as an additive, the reversibility of $\mathrm{LiBH}_{4}$ and $\mathrm{NaBH}_{4}$ was dramatically improved. ${ }^{7-10}$ However, this strategy does not work efficiently for 35 other metal borohydrides such as $\mathrm{Ca}\left(\mathrm{BH}_{4}\right)_{2} ., 11,12$ Also, the introduction of metal or metal hydrides will unavoidably lower the hydrogen capacity of the system, e.g., from $18.4 \mathrm{wt} \% \mathrm{H}$ for $\mathrm{LiBH}_{4}$ to $11.4 \mathrm{wt} \% \mathrm{H}$ for $\mathrm{LiBH}_{4}-0.5 \mathrm{Al}$.

A number of studies have been conducted aiming to alter 40 the reaction pathway of $\mathrm{Ca}\left(\mathrm{BH}_{4}\right)_{2}$, including the methods of additive addition, ${ }^{13-16}$ combination with other complex hydrides, ${ }^{17-19}$ nanoconfinement, ${ }^{20,21}$ application of external $\mathrm{H}_{2}$ pressure, ${ }^{22}$ etc. However, all of these methods showed limited effect on avoiding the formation of boron sinks toward full ${ }_{45}$ reversibility of $\mathrm{Ca}\left(\mathrm{BH}_{4}\right)_{2}$. The full rehydrogenation to $\mathrm{Ca}\left(\mathrm{BH}_{4}\right)_{2}$ has been considered impossible unless a very high $\mathrm{H}_{2}$ pressure is applied, i.e. 400 to 700 bar $\mathrm{H}_{2}$ at 400 to $440^{\circ} \mathrm{C}^{5,13,15,23-25}$
In present study, we identified the formation of $\mathrm{CaB}_{2} \mathrm{H}_{6}$ as the ${ }_{50}$ crucial intermediate step on the way to $\mathrm{CaB}_{6}$, which only forms below $370^{\circ} \mathrm{C}$. Thereby by controlling the decomposition temperature at 320 to $350^{\circ} \mathrm{C}$, the formation of boron sinks such as amorphous boron was efficiently avoided and $\mathrm{Ca}\left(\mathrm{BH}_{4}\right)_{2}$ was decomposed in $\mathrm{CaB}_{6}$ and $\mathrm{CaH}_{2}$, which facilitate the reversibly 55 absorption of hydrogen under much mild conditions. This study provides new insides into the decomposition mechanism of $\mathrm{Ca}\left(\mathrm{BH}_{4}\right)_{2}$ as well as instructions for further development of $\mathrm{Ca}\left(\mathrm{BH}_{4}\right)_{2}$ as a hydrogen storage material.

The decomposition of $\mathrm{Ca}\left(\mathrm{BH}_{4}\right)_{2}$ was carried out at 320 to ${ }_{60} 450^{\circ} \mathrm{C}$ under dynamic vacuum. The ${ }^{11} \mathrm{~B}$ MAS NMR spectra of the solid residue after decomposition are shown in Fig. 1. After dehydrogenation at $320^{\circ} \mathrm{C}$ for 6 to $20 \mathrm{~h}$ and $350^{\circ} \mathrm{C}$ for $6 \mathrm{~h}$, three resonances were observed, i.e., undecomposed $\mathrm{Ca}\left(\mathrm{BH}_{4}\right)_{2}$ at -31.0 $\mathrm{ppm}$, an intermediate centered at $-14 \mathrm{ppm}$ and newly formed ${ }_{65} \mathrm{CaB}_{6}$ centered at $11 \mathrm{ppm}^{24}$ In the sample dehydrogenated at $350^{\circ} \mathrm{C}$ for $20 \mathrm{~h}$, all B-H species disappeared where no B-H signal was detected in the ${ }^{11} \mathrm{~B}-{ }^{1} \mathrm{H}$ CP-MAS NMR spectrum. Only the resonance assigned to $\mathrm{CaB}_{6}$ was observed, indicating the full decomposition of $\mathrm{Ca}\left(\mathrm{BH}_{4}\right)_{2}$ into $\mathrm{CaB}_{6}$ and $\mathrm{CaH}_{2}$. Also, $9.5 \mathrm{wt} \%$ 70 of released hydrogen was recorded during the dehydrogenation process at $350^{\circ} \mathrm{C}$ for $20 \mathrm{~h}$ and in agreement with Eq. 1. In contrast, in the samples decomposed at 400 and $450^{\circ} \mathrm{C}$, only broad resonances centered at $0 \mathrm{ppm}$, which is assigned to amorphous boron, were observed in the ${ }^{11} \mathrm{~B}$ MAS NMR spectra 75 (Figs. 1c and d). These observations reveal an obvious temperature dependence of the decomposition pathway of $\mathrm{Ca}\left(\mathrm{BH}_{4}\right)_{2}$.

Due to the full decomposition into $\mathrm{CaB}_{6}$ at $350^{\circ} \mathrm{C}(20 \mathrm{~h})$, the reversibility of $\mathrm{Ca}\left(\mathrm{BH}_{4}\right)_{2}$ was achieved under relatively moderate 80 conditions (300 to $350{ }^{\circ} \mathrm{C}, 130$ to 185 bar $\mathrm{H}_{2}$ ). At $300{ }^{\circ} \mathrm{C}$, $\mathrm{Ca}\left(\mathrm{BH}_{4}\right)_{2}$ was partially recovered, as observed by ${ }^{11} \mathrm{~B}$ MAS NMR (Fig. 2). Almost all the boron was transformed back to $\mathrm{Ca}\left(\mathrm{BH}_{4}\right)_{2}$ at $350{ }^{\circ} \mathrm{C}$. This is a major breakthrough compared to the necessary temperatures $\left(400\right.$ to $\left.440^{\circ} \mathrm{C}\right)$ and pressures $(400$ to 700 85 bar) reported in the past. ${ }^{17,25}$ The rehydrogenation conditions for $\mathrm{Ca}\left(\mathrm{BH}_{4}\right)_{2}$ are also much more favorable than the those for $\mathrm{LiBH}_{4}$ and $\mathrm{Mg}\left(\mathrm{BH}_{4}\right)_{2}$, where the rehydrogenation from the dehydrogenation products requires $600^{\circ} \mathrm{C}$ and 155 to 350 bar $\mathrm{H}_{2},{ }^{26,27}$ and $400^{\circ} \mathrm{C}$ and 950 bar $\mathrm{H}_{2},{ }^{28}$ respectively. 

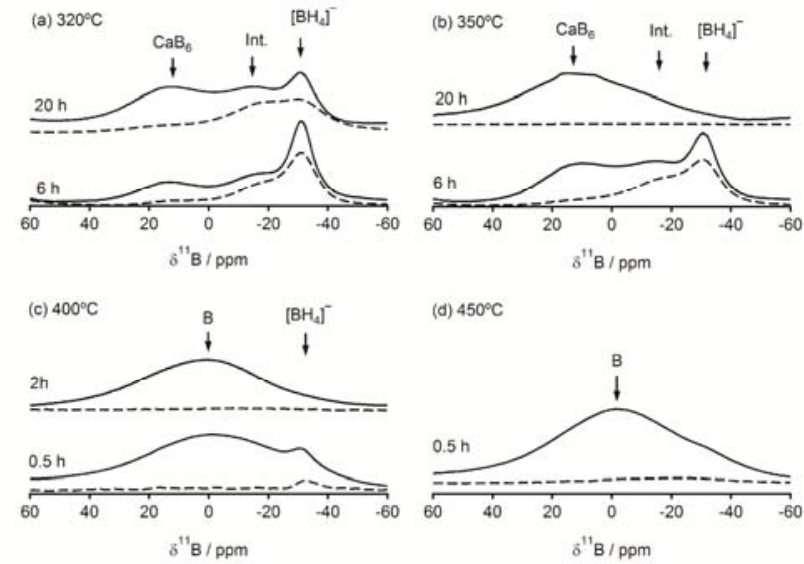

(d) $450^{\circ} \mathrm{C}$

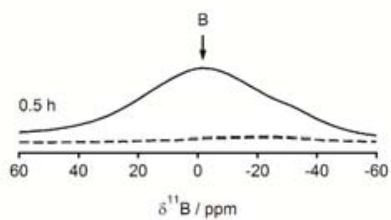

Fig. $1{ }^{11} \mathrm{~B}$ MAS NMR spectra of $\mathrm{Ca}\left(\mathrm{BH}_{4}\right)_{2}$ after $\mathrm{H}_{2}$ desorption under vacuum at 320 to $450^{\circ} \mathrm{C}$. In (a) and (b), the resonance centered at $-14 \mathrm{ppm}$ indicates the formation of an intermediate 5 (labelled Int.). Dashed lines represent the ${ }^{11} \mathrm{~B}$ CP-MAS NMR spectra.

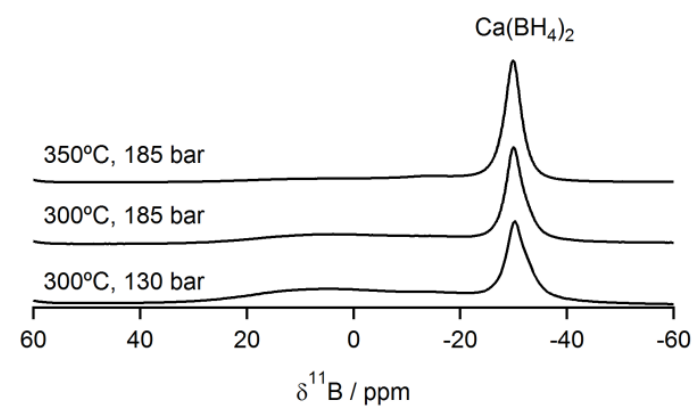

Fig. $2{ }^{11} \mathrm{~B}$ MAS NMR spectra of rehydrogenated $\mathrm{Ca}\left(\mathrm{BH}_{4}\right)_{2}$ at 300 10 to $350^{\circ} \mathrm{C}$ under 130 to 185 bar $\mathrm{H}_{2}$. Before rehydrogenation, $\mathrm{Ca}\left(\mathrm{BH}_{4}\right)_{2}$ was fully dehydrogenated at $350^{\circ} \mathrm{C}$ for $20 \mathrm{~h}$.

To investigate the temperature dependence of the decomposition reaction, samples of $\mathrm{Ca}\left(\mathrm{BH}_{4}\right)_{2}$ partially 15 decomposed at 320 to $400^{\circ} \mathrm{C}$ were dissolved in $\mathrm{D}_{2} \mathrm{O}$, in order to identify the reaction intermediates by solution-state ${ }^{11} \mathrm{~B}$ NMR (Fig. 3). In all the samples decomposed, the widely discussed intermediate, the $\left[\mathrm{B}_{12} \mathrm{H}_{12}\right]^{2-}$ species, were not observed. Instead, a new resonance at $-13.0 \mathrm{ppm}$ was observed when $\mathrm{Ca}\left(\mathrm{BH}_{4}\right)_{2}$ 20 decomposed 320 to $350^{\circ} \mathrm{C}$. It displayed a quartet splitting with a coupling constant $J_{\mathrm{B}-\mathrm{H}}$ of $87 \mathrm{~Hz}$ (Fig. 3b), indicating the presence of $\left[\mathrm{BH}_{3}\right]$ units as $\left[\mathrm{BH}_{3} \cdot \mathrm{OH}\right]^{-}$in aqueous solution. ${ }^{29}$ The structure of $\left[\mathrm{BH}_{3} \cdot \mathrm{OH}\right]^{-}$is shown in Fig. S1(†ESI) and the chemical shift of $\left[\mathrm{BH}_{3} \cdot \mathrm{OH}\right]^{-}$was calculated to be -12.9 to $-13.5 \mathrm{ppm}$ (Table 1), in 25 agreement with the experimental value.

To verify whether the formation of $\left[\mathrm{BH}_{3} \cdot \mathrm{OH}\right]^{-}$results from the hydrolysis of undecomposed $\mathrm{Ca}\left(\mathrm{BH}_{4}\right)_{2}$ in water or indicates the presence of a new intermediate, several control experiments were carried out. First, we investigated the hydrolysis of pure ${ }_{30} \mathrm{Ca}\left(\mathrm{BH}_{4}\right)_{2}$. Since the presence of $\mathrm{CaH}_{2}$ in the decomposition products of $\mathrm{Ca}\left(\mathrm{BH}_{4}\right)_{2}$ will produce alkaline solutions when it reacts with water, we dissolved pure $\mathrm{Ca}\left(\mathrm{BH}_{4}\right)_{2}$ in aqueous solutions with $\mathrm{pH}$ values from 7 to 14 . As shown in Fig. S2 $(† \mathrm{ESI})$, no $\left[\mathrm{BH}_{3} \cdot \mathrm{OH}\right]^{-}$was observed in the aqueous solutions of ${ }_{35} \mathrm{Ca}\left(\mathrm{BH}_{4}\right)_{2}$, regardless of $\mathrm{pH}$ values of the solution. This behavior

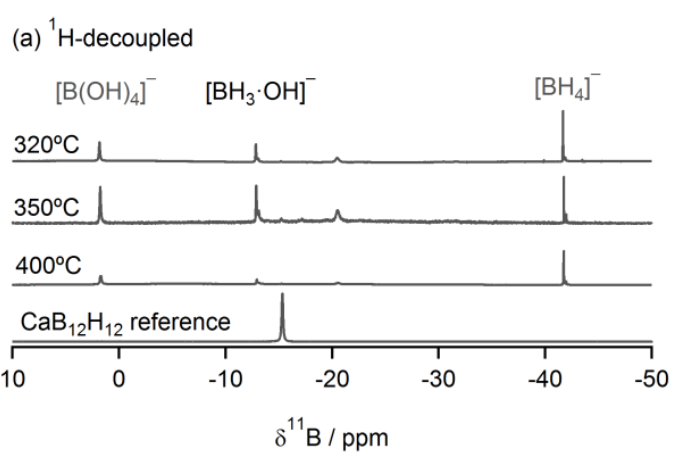

(b) ${ }^{1} \mathrm{H}$-coupled $\quad\left[\mathrm{BH}_{3} \cdot \mathrm{OH}\right]^{-}$

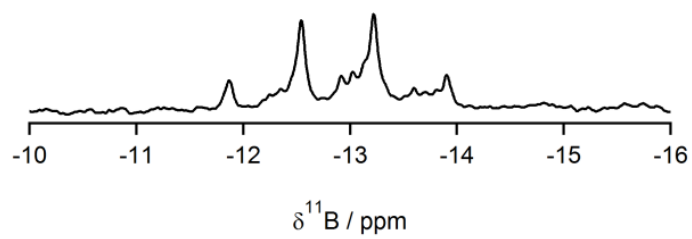

Fig. 3 (a) ${ }^{11} \mathrm{~B}\left\{{ }^{1} \mathrm{H}\right\}$ NMR spectra recorded of $\mathrm{Ca}\left(\mathrm{BH}_{4}\right)_{2}$ (dissolved in $\left.\mathrm{D}_{2} \mathrm{O}\right)$ after decomposition under vacuum at $320^{\circ} \mathrm{C}(6 \mathrm{~h}), 350^{\circ} \mathrm{C}$ $40(6 \mathrm{~h})$ and at $400{ }^{\circ} \mathrm{C}(0.5 \mathrm{~h})$, respectively. A reference sample of $\mathrm{CaB}_{12} \mathrm{H}_{12}$ shows its resonances at $-15.3 \mathrm{ppm}$. (b) ${ }^{1} \mathrm{H}$-coupled ${ }^{11} \mathrm{~B}$ NMR spectra of the resonance at $-13 \mathrm{ppm}$ in (a), displaying a quartet splitting of $\left[\mathrm{BH}_{3}\right]$ unit $\left(J_{\mathrm{B}-\mathrm{H}}\right.$ of $\left.87 \mathrm{~Hz}\right)$.

${ }_{45}$ Table 1. Absolute magnetic shielding values (ppm) and Chemical Shift (ppm) for different boron complexes calculated at B3LYP/6-311+G(2d,p) level of theory. ${ }^{30,31}$

\begin{tabular}{|c|c|c|c|c|}
\hline \multirow[b]{2}{*}{ Molecule } & \multirow[b]{2}{*}{ Atom } & \multirow{2}{*}{$\begin{array}{c}\text { Absolute } \\
\text { shielding } \\
\left(\delta^{11} \mathrm{~B} / \mathrm{ppm}\right)\end{array}$} & \multicolumn{2}{|c|}{ Chemical Shift $\left(\delta^{11} \mathrm{~B} / \mathrm{ppm}\right)$} \\
\hline & & & $\begin{array}{c}\text { Referred to } \\
\mathrm{B}_{2} \mathrm{H}_{6}\end{array}$ & $\begin{array}{l}\text { Referred to } \\
\mathrm{B}(\mathrm{OH})_{3}\end{array}$ \\
\hline $\mathrm{B}_{2} \mathrm{H}_{6}$ & B & 83.6 & - & - \\
\hline $\mathrm{B}(\mathrm{OH})_{3}$ & B & 81.4 & - & - \\
\hline $\mathrm{Ca}\left(\mathrm{BH}_{4}\right)_{2}$ & $\mathrm{~B} 1, \mathrm{~B} 2$ & 136.1 & -34.5 & $-35.1\left(-30.9^{[\mathrm{a}]}\right)$ \\
\hline$\left[\mathrm{B}_{2} \mathrm{H}_{6}\right]^{2-}$ & $\mathrm{B} 1, \mathrm{~B} 2$ & 138.5 & -36.9 & $-37.5\left(-31.4^{[b]}\right)$ \\
\hline$\left[\mathrm{BH}_{3} \cdot \mathrm{OH}\right]^{-}$ & $\mathrm{B}$ & 114.5 & -12.9 & $-13.5\left(-13.0^{[\mathrm{ad}]}\right)$ \\
\hline $\mathrm{CaB}_{2} \mathrm{H}_{6}$ & & & & \\
\hline Isomer 1 & $\mathrm{~B} 1, \mathrm{~B} 2$ & 105.0 & -3.4 & -4.0 \\
\hline Isomer $\mathbf{2}$ & B1, B2 & $91.7 \& 125.5$ & $9.9 \&-23.9$ & $9.3 \&-24.5$ \\
\hline
\end{tabular}

The chemical shift of $\mathrm{B}_{2} \mathrm{H}_{6}$ is $18 \mathrm{ppm}^{31}$ and that of $\mathrm{B}(\mathrm{OH})_{3}$ is $19.6 \mathrm{ppm}$ (measured in this work). In brackets we show the experimental value in 50 this work [a] and calculated value at "MP2/6-31G*" level in ref 16 [b].

differs from the alkline metal borohydrides, $\mathrm{LiBH}_{4}$ and $\mathrm{NaBH}_{4}$, which do produce $\left[\mathrm{BH}_{3} \cdot \mathrm{OH}\right]^{-}$when reacting with $\mathrm{D}_{2} \mathrm{O}$ (Fig. $\mathrm{S} 3$, $\dagger$ ESI).

55 Furthermore, in the alkaline solution $(\mathrm{pH}=14)$ of the partially decomposed $\mathrm{Ca}\left(\mathrm{BH}_{4}\right)_{2}\left(350^{\circ} \mathrm{C}\right.$, vacuum, $\left.6 \mathrm{~h}\right)$, the $\left[\mathrm{BH}_{3} \cdot \mathrm{OH}\right]^{-}$ species faded with time and converted to $\left[\mathrm{B}(\mathrm{OH})_{4}\right]^{-}$(Fig. S4, $\dagger$ ESI). In contrast, no obvious decay of $\left[\mathrm{BH}_{4}\right]^{-}$was observed within $20 \mathrm{~h}$. Also, the reaction of $\mathrm{CaB}_{6}$ with $\mathrm{D}_{2} \mathrm{O}(\mathrm{pH}=7$ to 14) 60 at room temperature does not lead to any formation of $\left[\mathrm{BH}_{3}\right]$ species (Fig. S5, †ESI). Therefore, the $\left[\mathrm{BH}_{3} \cdot \mathrm{OH}\right]^{-}$species did not result from the hydrolysis of $\mathrm{Ca}\left(\mathrm{BH}_{4}\right)_{2}$ or $\mathrm{CaB}_{6}$, and must originate from another intermediate formed from the decomposition of $\mathrm{Ca}\left(\mathrm{BH}_{4}\right)_{2}$. On the other hand, in the partially 


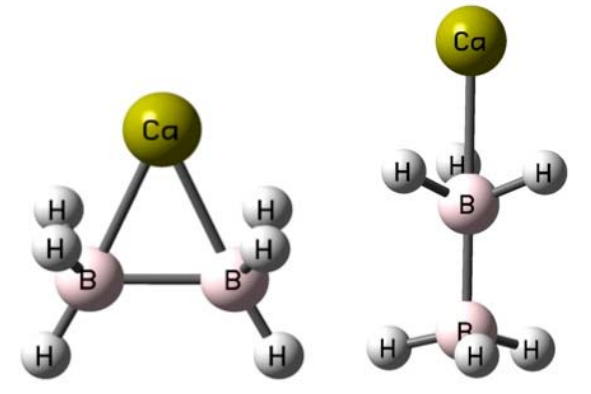

Isomer 1

Isomer 2

Fig. 4 Two possible isomers of $\mathrm{CaB}_{2} \mathrm{H}_{6}$ cluster

5 decomposed $\mathrm{Ca}\left(\mathrm{BH}_{4}\right)_{2}$ at $400^{\circ} \mathrm{C}$ (Fig. 2), only traces of $\left[\mathrm{BH}_{3} \cdot \mathrm{OH}\right]^{-}$was detected, indicating a different decomposition process. A more detailed study of the decomposition process at $400^{\circ} \mathrm{C}$ was carried out including the hydrogen back-pressures from 0 to 50 bar (Fig. S6, †ESI). Under these conditions, 10 amorphous boron was found to be the main decomposition product (Fig. S6a, †ESI). Other species including $\left[\mathrm{BH}_{3} \cdot \mathrm{OH}\right]^{-}$ were found only in traces (Fig. S6b, †ESI).

It is known that diborane splits into two $\left[\mathrm{BH}_{3}\right]$ units in organic solvents (e.g., THF). The $\left[\mathrm{BH}_{3} \cdot \mathrm{OH}\right]^{-}$species observed in this 15 study are very likely evidence for the formation of a $\left[\mathrm{B}_{2} \mathrm{H}_{6}\right]$ compound (i.e., $\mathrm{CaB}_{2} \mathrm{H}_{6}$ ), which analogously splits into two $\left[\mathrm{BH}_{3}\right]$ moieties in water. This process can be expressed by the below equation:

$$
\mathrm{CaB}_{2} \mathrm{H}_{6}+2 \mathrm{H}_{2} \mathrm{O} \rightarrow \mathrm{Ca}^{2+}+2\left[\mathrm{BH}_{3} \cdot \mathrm{OH}\right]^{-}+\mathrm{H}_{2}
$$

The $\left[\mathrm{B}_{2} \mathrm{H}_{6}\right]^{2-}$ anion is isostructural to the $\mathrm{C}_{2} \mathrm{H}_{6}$ ethane molecule, ${ }^{32}$ which has been reported as a ligand in some organometallic compounds. ${ }^{33-35} \mathrm{~K}_{2} \mathrm{~B}_{2} \mathrm{H}_{6}$ was successfully synthesized in THF ${ }_{25}$ solution from the reaction of $\mathrm{K}_{2} \mathrm{BH}_{3}$ and $\left[\mathrm{BH}_{3}\right]$ units. ${ }^{36}$ Recently, $\mathrm{MgB}_{2} \mathrm{H}_{6}$ has also been discussed, while the DFT predictions did not support $\mathrm{MgB}_{2} \mathrm{H}_{6}$ forming as an intermediate for the decomposition of $\mathrm{Mg}\left(\mathrm{BH}_{4}\right)_{2}$. $^{37-39}$

$\mathrm{CaB}_{2} \mathrm{H}_{6}$ has been predicted to be a stable compound with a 30 monoclinic crystal structure (space group, $C 2 / \mathrm{c}$ ), ${ }^{39}$ which shows two arrangements of isomer (Fig. 4). The ${ }^{11} \mathrm{~B}$ chemical shift of $\mathrm{CaB}_{2} \mathrm{H}_{6}$ were calculated (Table 1). Isomer 1 of $\mathrm{CaB}_{2} \mathrm{H}_{6}$ contains one type of boron atom showing a ${ }^{11} \mathrm{~B}$ chemical shift at $-4.0 \mathrm{ppm}$, and isomer 2 contains two types of boron atoms showing 35 chemical shifts at 9.3 and $-24.5 \mathrm{ppm}$, referred to $\mathrm{B}(\mathrm{OH})_{3}$. The coexistence of these three types of boron atoms would result in a broad ${ }^{11} \mathrm{~B}$ resonance. Experimentally, a new broad resonance centered at $-14 \mathrm{ppm}$ was observed by ${ }^{11} \mathrm{~B}$ MAS NMR in the partially decomposed $\mathrm{Ca}\left(\mathrm{BH}_{4}\right)_{2}$ at 320 and $350{ }^{\circ} \mathrm{C}$ (Figs. 1a and $40 \mathrm{~b}$ ), which was not found when $\mathrm{Ca}\left(\mathrm{BH}_{4}\right)_{2}$ decomposed at 400 and $450^{\circ} \mathrm{C}$ (Figs. 1c and d). Since $\mathrm{CaB}_{12} \mathrm{H}_{12}$, with a chemical shift of $15 \mathrm{ppm}$, was ruled out as a reaction intermediate by solution-state ${ }^{11} \mathrm{~B}$ NMR measurement (Fig. 2), this new resonance was reasonably assigned to $\mathrm{CaB}_{2} \mathrm{H}_{6}$.

45 Based on the structures shown in Fig. 4, the IR spectra of $\mathrm{CaB}_{2} \mathrm{H}_{6}$ isomers were calculated (Fig. S7, $\dagger \mathrm{ESI}$ ). The internal B$\mathrm{H}$ vibrations of $\mathrm{CaB}_{2} \mathrm{H}_{6}$, i.e. stretching modes mainly at 2000 to $2500 \mathrm{~cm}^{-1}$ and bending modes at around $1100 \mathrm{~cm}^{-1}$, are close to those of $\mathrm{Ca}\left(\mathrm{BH}_{4}\right)_{2}$. Accordingly, in the samples of $\mathrm{Ca}\left(\mathrm{BH}_{4}\right)_{2}$ so decomposed at $350^{\circ} \mathrm{C}$ for 2 to $6 \mathrm{~h}$, we observed broad resonances by FT-IR at around 2200 and $1100 \mathrm{~cm}^{-1}$ which are possibly from the combination of $\left[\mathrm{BH}_{4}\right]$ and $\left[\mathrm{B}_{2} \mathrm{H}_{6}\right]$. Furthermore, vibration

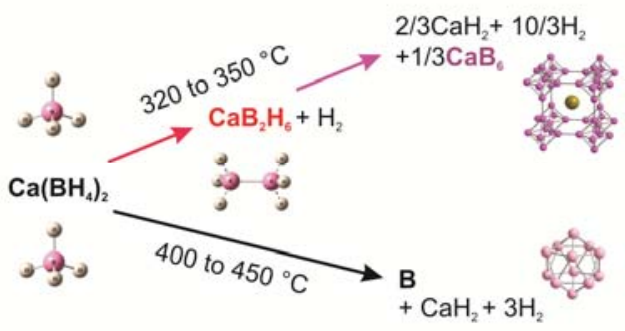

Scheme 1. Temperature-dependent decomposition pathway of ${ }_{55} \mathrm{Ca}\left(\mathrm{BH}_{4}\right)_{2}$.

modes around 600 to $800 \mathrm{~cm}^{-1}$ observed by FTIR (Fig. S7, $\uparrow$ ESI) are identified with the predicted B-B stretching modes of $\left[\mathrm{B}_{2} \mathrm{H}_{6}\right]$.

Above all, we identified the formation of $\mathrm{CaB}_{2} \mathrm{H}_{6}$ as the crucial 60 intermediate step on the way to $\mathrm{CaB}_{6}$, which only forms at 320 to $350^{\circ} \mathrm{C}$. This selective formation allows controlling decomposition of $\mathrm{Ca}\left(\mathrm{BH}_{4}\right)_{2}$ by reaction temperature, as shown in Scheme 1. As a result, the decomposition of $\mathrm{Ca}\left(\mathrm{BH}_{4}\right)_{2}$ at 320 to $350^{\circ} \mathrm{C}$ circumvents the formation of boron sinks such as amorphous 65 boron, which facilitates the reversibly absorption of hydrogen under much mild conditions. The two distinct decomposition behavior at 320 to $350^{\circ} \mathrm{C}$ and at 400 to $450^{\circ} \mathrm{C}$ may be related to different physical states of $\mathrm{Ca}\left(\mathrm{BH}_{4}\right)_{2}$ which was reported to melt above $370^{\circ} \mathrm{C} .^{40}$

70 To further understand the formation of $\mathrm{CaB}_{2} \mathrm{H}_{6}$ as an intermediate of $\mathrm{Ca}\left(\mathrm{BH}_{4}\right)_{2}$ from an energetic viewpoint, we carried out first principles cluster calculations. The geometries of the $\mathrm{Ca}$ salts including $\mathrm{Ca}\left(\mathrm{BH}_{4}\right)_{2}, \mathrm{CaB}_{2} \mathrm{H}_{6}, \mathrm{Ca}\left(\mathrm{B}_{3} \mathrm{H}_{8}\right)_{2}$ and $\mathrm{CaB}_{12} \mathrm{H}_{12}$ are shown in Fig. $\mathrm{S} 9(\dagger \mathrm{ESI})$. In all these $\mathrm{CaB}_{x} \mathrm{H}_{y}$ salts, there are two 75 different types of $\mathrm{H}$ atoms, one being positive while the other being negative. For example, in the gas phase $\mathrm{Ca}\left(\mathrm{BH}_{4}\right)_{2}$ cluster forms a linear chain with the $\mathrm{Ca}^{2+}$ being inserted between two $\left[\mathrm{BH}_{4}\right]^{-}$units. One type of $\mathrm{H}$ atoms carries a charge of -0.08 and the other $+0.21 \mathrm{e}$. It is expected that in $\mathrm{Ca}\left(\mathrm{BH}_{4}\right)_{2}$, the two 80 oppositely charged $\mathrm{H}$ atoms will combine and desorb as a $\mathrm{H}_{2}$ molecule forming $\mathrm{CaB}_{2} \mathrm{H}_{6}$. Furthermore, we found that among all $\mathrm{Ca}$ salts, $\mathrm{CaB}_{2} \mathrm{H}_{6}$ is the most strongly bound salt followed by $\mathrm{Ca}\left(\mathrm{BH}_{4}\right)_{2}, \mathrm{Ca}\left(\mathrm{B}_{3} \mathrm{H}_{8}\right)_{2}$ and $\mathrm{CaB}_{12} \mathrm{H}_{12}$ (Table $\mathrm{S} 2, \dagger \mathrm{ESI}$ ). This suggests that during the decomposition of $\mathrm{Ca}\left(\mathrm{BH}_{4}\right)_{2}$, the most 85 preferred intermediate phase is $\mathrm{CaB}_{2} \mathrm{H}_{6}$ (Table $\mathrm{S} 3$, $† \mathrm{ESI}$ ).

In summary, we reported a simple and efficient route to close the hydrogen sorption cycle for pure $\mathrm{Ca}\left(\mathrm{BH}_{4}\right)_{2}$ under moderate conditions. Namely, $\mathrm{Ca}\left(\mathrm{BH}_{4}\right)_{2}$ releases $9.5 \mathrm{wt} \% \mathrm{H}$ at 320 to $350^{\circ} \mathrm{C}$ via decomposition into $\mathrm{CaB}_{6}$ and $\mathrm{CaH}_{2}$ without formation 90 of boron sinks such as amorphous boron and $\mathrm{CaB}_{12} \mathrm{H}_{12}$, and rehydrogenation is achieved at the same temperatures and under 130 to 185 bar $\mathrm{H}_{2}$. This affirms that $\mathrm{Ca}\left(\mathrm{BH}_{4}\right)_{2}$ is still a promising candidate for reversible hydrogen storage. No additives or catalysts were used in the present study, leaving enough room for 95 further improvement of the hydrogen sorption performance of $\mathrm{Ca}\left(\mathrm{BH}_{4}\right)_{2}$ for practical applications.

\section{Notes and references}

${ }^{a}$ EMPA, Swiss Federal Laboratories for Materials Science and Technology, Materials for Energy Conversion, 8600 Dübendorf, 100 Switzerland. Fax: +41 5876540 22; Tel: +415876540 82; yigang.yan@empa.ch.

${ }^{b}$ EMPA, Swiss Federal Laboratories for Materials Science and Technology, Hydrogen \& Energy, 8600 Dübendorf, Switzerland.

${ }^{\circ} E M P A, \quad$ Swiss Federal Laboratories for Materials Science and 105 Technology, Functional Polymers, 8600 Dübendorf, Switzerland.

${ }^{d}$ École Polytechnique Fédérale de Lausanne (EPFL), Institut des Sciences et Ingénierie Chimique, Lausanne, Switzerland. 
${ }^{e}$ Physics Department, Virginia Commonwealth University, Richmond, VA 23284, USA

$\uparrow$ Electronic Supplementary Information (ESI) available: Methods, optimized Geometries and optimized cartesian coordinates of $\left[\mathrm{BH}_{3} \cdot \mathrm{OH}\right]^{-}$,

${ }_{5}{ }^{11} \mathrm{~B}$ NMR spectra of hydrolysis products of $\mathrm{Ca}\left(\mathrm{BH}_{4}\right)_{2}, \mathrm{NaBH}_{4}, \mathrm{LiBH}_{4}$ and

$\mathrm{CaB}_{6}$ in aqueous solutions with different $\mathrm{pH}$ values, decay of $\left[\mathrm{BH}_{3} \cdot \mathrm{OH}\right]^{-}$ in alkaline solution, ${ }^{11} \mathrm{~B}$ NMR spectra of $\mathrm{Ca}\left(\mathrm{BH}_{4}\right)_{2}$ decomposed at $400^{\circ} \mathrm{C}$ under different $\mathrm{H}_{2}$ external pressures, calculated IR of $\mathrm{CaB}_{2} \mathrm{H}_{6}$ isomers compared to experimental IR observations, first principles cluster 10 calculations. See DOI: 10.1039/b000000x/

1. A. Zuttel, A. Remhof, A. Borgschulte and O. Friedrichs, Philos T R Soc A, 2010, 368, 3329-3342.

2. P. Jena, The Journal of Physical Chemistry Letters, 2011, 2 206-211.

153 H. W. Li, Y. G. Yan, S. Orimo, A. Zuttel and C. M. Jensen, Energies, 2011, 4, 185-214.

4. K. Miwa, M. Aoki, T. Noritake, N. Ohba, Y. Nakamori, S. Towata, A. Zuttel and S. Orimo, Phys Rev B, 2006, 74

5. Y. Kim, D. Reed, Y. S. Lee, J. Y. Lee, J. H. Shim, D. Book and Y. W. Cho, J Phys Chem C, 2009, 113, 5865-5871.

6. V. Ozolins, E. H. Majzoub and C. Wolverton, J Am Chem Soc, 2009, 131, 230-237

7. J. J. Vajo, S. L. Skeith and F. Mertens, J Phys Chem B, 2005 109, 3719-3722.

$258 . \quad$ X.-D. Kang, P. Wang, L.-P. Ma and H.-M. Cheng, Appl. Phys. $A, 2007, \mathbf{8 9}, 963-966$.

9. J. F. Mao, X. B. Yu, Z. P. Guo, H. K. Liu, Z. Wu and J. Ni, $J$ Alloy Compd, 2009, 479, 619-623.

10. D. B. Ravnsbaek and T. R. Jensen, J Appl Phys, 2012, 111.

3011 G. Barkhordarian, T. R. Jensen, S. Doppiu, U. Bosenberg, A Borgschulte, R. Gremaud, Y. Cerenius, M. Dornheim, T. Klassen and R. Bormann, J Phys Chem C, 2008, 112, 27432749.

12. C. B. Minella, C. Pistidda, S. Garroni, P. Nolis, M. D. Baro, O 35 Gutfleisch, T. Klassen, R. Bormann and M. Dornheim, J Phys Chem C, 2013, 117, 3846-3852.

13. E. Ronnebro and E. H. Majzoub, J Phys Chem B, 2007, 111, 12045-12047.

14. J. H. Kim, J. H. Shim and Y. W. Cho, J Power Sources, 2008 181, 140-143.

15. C. B. Minella, S. Garroni, C. Pistidda, R. Gosalawit-Utke, G. Barkhordarian, C. Rongeat, I. Lindemann, O. Gutfleisch, T. R. Jensen, Y. Cerenius, J. Christensen, M. D. Baro, R. Bormann, T. Klassen and M. Dornheim, J Phys Chem C, 2011, 115, 2497-2504.

16. J. Gu, M. X. Gao, H. G. Pan, Y. F. Liu, B. Li, Y. J. Yang, C Liang, H. L. Fu and Z. X. Guo, Energ Environ Sci, 2013, 6, 847-858.

17. H. L. Chu, Z. T. Xiong, G. T. Wu, J. P. Guo, T. He and P. 50 Chen, Dalton T, 2010, 39, 10585-10587.

18. Y. G. Yan, A. Remhof, P. Mauron, D. Rentsch, Z. Lodziana, Y. S. Lee, H. S. Lee, Y. W. Cho and A. Zuttel, J Phys Chem $C, 2013, \mathbf{1 1 7}, 8878-8886$.

19. A. A. Ibikunle and A. J. Goudy, Int J Hydrogen Energ, 2012, 55 37, 12420-12424.

20. H. S. Lee, Y. S. Lee, J. Y. Suh, M. Kim, J. S. Yu and Y. W. Cho, J Phys Chem C, 2011, 115, 20027-20035.

21. C. Comanescu, G. Capurso and A. Maddalena, Nanotechnology, 2012, 23.

$6022 . \quad$ Y. Kim, S. J. Hwang, Y. S. Lee, J. Y. Suh, H. N. Han and Y. W. Cho, J Phys Chem C, 2012, 116, 25715-25720.

23. L. L. Wang, D. D. Graham, I. M. Robertson and D. D Johnson, J Phys Chem C, 2009, 113, 20088-20096.

24. C. B. Minella, S. Garroni, D. Olid, F. Teixidor, C. Pistidda, I 65 Lindemann, O. Gutfleisch, M. D. Baro, R. Bormann, T. Klassen and M. Dornheim, J Phys Chem C, 2011, 115, 1801018014.

25. H.-W. Li, E. Akiba and S.-i. Orimo, J Alloy Compd, 2013 580, Supplement 1, S292-S295.

7026 S. Orimo, Y. Nakamori, G. Kitahara, K. Miwa, N. Ohba, S. Towata and A. Zuttel, J Alloy Compd, 2005, 404, 427-430.
P. Mauron, F. Buchter, O. Friedrichs, A. Remhof, M. Bielmann, C. N. Zwicky and A. Zuttel, J Phys Chem B, 2008 , 112, 906-910.

$7528 . \quad$ G. Severa, E. Ronnebro and C. M. Jensen, Chem Commun, 2010, 46, 421-423.

29. J. A. Gardiner and J. W. Collat, J Am Chem Soc, 1964, 86, 3165-\&.

30. B. Wrackmeyer and O. L. Tok, Z Naturforsch B, 2007, 62 , 220-224

80

31. B. Wrackmeyer, Z Naturforsch B, 2004, 59, 1192-1199.

32. J. K. Olson and A. I. Boldyrev, Chem Phys Lett, 2012, 523, 83-86.

33. H. D. Kaesz, W. Fellmann, G. R. Wilkes and L. F. Dahl, J Am Chem Soc, 1965, 87, 2753-2755.

34. S. Aldridge, M. Shang and T. P. Fehlner, J Am Chem Soc, 1998, 120, 2586-2598.

35. D. K. Roy, S. K. Bose, K. Geetharani, K. K. Varma Chakrahari, S. M. Mobin and S. Ghosh, Chemistry - A European Journal, 2012, 18, 9983-9991.

36. R. A. Godfroid, T. G. Hill, T. P. Onak and S. G. Shore, J Am Chem Soc, 1994, 116, 12107-12108.

37. Y. G. Yan, H. W. Li, H. Maekawa, M. Aoki, T. Noritake, M. Matsumoto, K. Miwa, S. Towata and S. Orimo, Mater Trans, 2011, 52, 1443-1446.

38. G. L. Soloveichik, Y. Gao, J. Rijssenbeek, M. Andrus, S. Kniajanski, R. C. Bowman, S. J. Hwan and J. C. Zhao, Int $J$ Hydrogen Energ, 2009, 34, 916-928.

39. Y. S. Zhang, E. Majzoub, V. Ozolins and C. Wolverton, Phys Rev B, 2010, 82

40. M. Paskevicius, M. B. Ley, D. A. Sheppard, T. R. Jensen and C. E. Buckley, Phys Chem Chem Phys, 2013, 15, 19774 19789.

4 | Journal Name, [year], [vol], oo-oo 